\title{
editorial
}

\section{SUPERPOSICIONES: IDEAS Y ACCIONES PARA LA TRANSFORMACIÓN DEL TERRITORIO}

\author{
SUPERIMPOSITIONS: IDEAS AND ACTIONS FOR TRANSFORMING THE LANDSCAPE
}

Rosa María Añón Abajas

\section{SUMMARY}

The objective of the journal is to be an active agent of research in architecture and urbanism and to contribute to the production of constructive debate. There are as many ideas about landscape as there are ideas about architecture and here we attempt to explore some of them. The articles in this issue are heterogeneous, diverse and, simultaneously, full of coincidences, for that reason I believe they need to be read without haste.

Reflections are offered on the origin of the concept of architecture in opposition to nature, on contradiction, dialectic discourse, debate and evolution. The planning process is vindicated as a continuum between learning and creative contribution. It is indiscriminate. All architecture, whether small or localized, has a responsibility within the construction of the landscape. The plurality of public space, the new ways of producing urban space and its history from the ethnographic artists are all observed. The theories distilled from this cocktail of ideas serve to lead us to a state, independent of the passage of time, to revive specific and current problems such as the regeneration of obsolete, social housing districts. This vindicates the need to manage urban-planning operations with full architectural control.

Several authors show us, through works and critical reflection, how the architect can make a long-term research project of their career. In order to bring the experience of successive sources of superimposed thoughts to a consistent closure, we have recovered an unpublished article by the lecturer Manuel Trillo de Leyva, which is current, pertinent, multiffaceted and integrates all the contributions in a balanced and essential way. His analysis on Foster's intervention in the Reichstag reveals the integrating position that architecture should occupy within history. 